\title{
PENGETAHUAN, SIKAP DAN MOTIVASI PERAWAT PELAKSANA TENTANG KESELAMATAN PASIEN TERKAIT KEBERSIHAN TANGAN DI RUANG RAWAT INAP RUMAH SAKIT UMUM DAERAH KABUPATEN BULELENG
}

\author{
Luh Ayu Ristayani*, Rina Listyowati \\ Program Studi Kesehatan Masyarakat Fakultas Kedokteran Universitas Udayana \\ ${ }^{*}$ Email: ayuristayani10@gmail.com
}

\begin{abstract}
ABSTRAK
Rumah sakit wajib menerapkan standar keselamatan pasien yaitu pengurangan risiko infeksi terkait pelayanan kesehatan untuk meningkatkan mutu pelayanan. Namun, kejadian infeksi rumah sakit masih banyak ditemukan. Salah satu program mengurangi infeksi yaitu kebersihan tangan. Keberhasilan program disebabkan oleh beberapa faktor sehingga tujuan penelitian ini untuk mengetahui pengetahuan, sikap dan motivasi perawat tentang keselamatan pasien terkait kebersihan tangan. Jenis penelitian yaitu deskriptif kuantitatif cross sectional. Sampel sebanyak 105 perawat di ruang rawat inap RSUD Kabupaten Buleleng dengan teknik proportionated random sampling. Pengumpulan data dengan metode kuesioner dan dianalisis univariat. Hasil penelitian menunjukkan 57,1\% responden memiliki pengetahuan baik dan hanya 14,3\% yang kurang, 68,6\% sikap positif dan $60,0 \%$ motivasi tinggi. Pengetahuan baik dan sikap positif cenderung pada umur $\geq 30$ tahun, perempuan, pendidikan S1/Ners, masa kerja $>10$ tahun dan status kepegawaian tetap. Motivasi tinggi cenderung pada responden umur $\geq 30$ tahun, jenis kelamin laki-laki, pendidikan S1/Ners, masa kerja $>10$ tahun dan status kepegawaian tetap. Sebagian besar responden sudah memiliki pengetahuan baik, sikap positif dan motivasi tinggi. Diharapkan rumah sakit dapat memberikan motivasi kepada petugas untuk meningkatkan kinerja, pelatihan berkala dan sosialisasi mendalam mengenai keselamatan pasien terutama sasaran pengurangan risiko infeksi pelayanan kesehatan termasuk kebersihan tangan.
\end{abstract}

Kata kunci: Keselamatan pasien, Kebersihan Tangan, Pengetahuan, Sikap, Motivasi

\section{ABSTRACT}

Hospitals must implement patient safety standards, namely reducing the risk of infection related to health services to improve the quality of service. However, the incidence of hospital infections is still commonly found. One program to reduce infection is hand hygiene. The success of the program is caused by several factors so the purpose of this study is to find out nurses' knowledge, attitudes and motivations regarding patient safety related to hand hygiene. This type of research is descriptive cross sectional descriptive. A sample of 105 nurses in the inpatient ward of Buleleng Regency Hospital using proportionated random sampling technique. Data collection by questionnaire method and univariate analysis. The results showed $57.1 \%$ of respondents had good knowledge and only $14.3 \%$ were lacking, $68.6 \%$ positive attitude and $60.0 \%$ high motivation. Good knowledge and positive attitudes tend to be $\geq 30$ years old, women, S1 / Nurse education, tenure of $>10$ years and permanent employment status. High motivation tends to be respondents aged $\geq 30$ years, male sex, education S1 / Nurse, tenure of $>10$ years and permanent employment status. Most respondents already have good knowledge, positive attitude and high motivation. It is expected that the hospital can provide motivation to officers to improve performance, regular training and in-depth socialization on patient safety, especially the target of reducing the risk of health care infections including hand hygiene.

Keywords: Patient Safety, Hand Hygiene, Knowledge, Attitude, Motivation

\section{PENDAHULUAN}

Terdapat lima isu keselamatan yang ada dirumah sakit, salah satunya yaitu keselamatan pasien (Kemenkes RI, 2008). Keselamatan pasien menjadi masalah global yang digunakan sebagai standar rumah sakit dalam upaya peningkatan mutu meliputi sasaran keselamatan pasien meliputi ketepatan identitas, peningkatan komunikasi efektif, peningkatan pemberian obat yang perlu diwaspadai, ketepatan lokasi, prosedur, dan pasien operasi, pengurangan risiko pasien jatuh dan pengurangan risiko infeksi terkait 
pelayanan kesehatan. Infeksi terkait pelayanan kesehatan atau Health Care Associated Infections (HAIs) merupakan infeksi selama perawatan rumah sakit, ketika pasien masuk tidak ada infeksi dan tidak dalam masa inkubasi serta muncul akibat proses pelayanan kesehatan (Kemenkes RI, 2017).

Menurut Utarini (2011) dalam Ningsih, dkk (2017), insiden yang sering terjadi yaitu kesalahan pengobatan, prosedur serta infeksi terkait pelayanan kesehatan. Di beberapa negara Eropa dan Amerika kejadian infeksi meningkat dari 1\% serta lebih dari 40\% di Asia, Afrika dan Amerika Latin. Kejadian infeksi di RS Asia sekitar 3-21\% dengan rata-rata 9\% (Kemenkes RI, 2011).

Dampak kejadian infeksi dapat merugikan rumah sakit, petugas kesehatan, dan terutama pasien seperti bertambahnya lama proses perawatan pasien sehingga biaya pengobatan akan semakin banyak. Kejadian infeksi juga dapat menyebabkan menurunnya kepercayaan pasien (Al-tawfiq dan Tambyah, 2014). Berdasarkan pengambilan data, masih terjadi beberapa kejadian infeksi cenderung mengalami peningkatan persentase yaitu sebanyak 0,47\% tahun 2016 dan 0,87\%tahun 2017. Infeksi luka operasi (ILO) sebanyak 0,54\% bulan Juni, 1,63\% bulan Agustus, dan $2,64 \%$ bulan Oktober 2017. Selain itu, terdapat jenis infeksi yang biasa muncul di rumah sakit masih terjadi.

Pengurangan risiko infeksi dalam sasaran keselamatan pasien dilaksanakan dengan menerapkan standar kebersihan tangan. WHO mencanangkan program Global Patient Safety Challenge "Clean Care is Safer Care" sebagai sebuah komitmen menurunkan infeksi melalui kebersihan tangan 6 langkah 5 momen yang memiliki peran terbesar penyebaran infeksi pelayanan kesehatan (WHO, 2009). Menurut CDC (2014), penyedia layanan kesehatan harus membudayakan dan menerapkan kebersihan tangan dalam keselamatan pasien terutama sebelum kontak pasien, setelah kontak cairan tubuh/darah, setelah prosedur invasif, setelah melepaskan sarung tangan.

Berdasarkan studi pendahuluan, secara umum pelaksanaan kebersihan tangan di RSUD Kabupaten Buleleng mengalami penurunan yaitu Triwulan II sebesar $87,3 \%$, Triwulan III sebesar $82,9 \%$ dan Triwulan IV sebesar $80,7 \%$ pada tahun 2017. Upaya yang sudah dibuat manajemen rumah sakit yaitu membuat kebijakan, prosedur dan menyediakan fasilitas pendukung. Petugas kesehatan salah satunya perawat berwenang dalam melakukan tindakan dan memiliki waktu paling banyak dengan pasien. Perawat berperan besar dalam mencegah terjadinya insiden keselamatan pasien termasuk penyebaran infeksi melalui pengkajian risiko dalam memberikan asuhan keperawatan atau pelayanan (Malliarou, 2017). Menurut WHO (2009), angka infeksi nosokomial menurun apabila terjadi peningkatan kepatuhan kebersihan tangan dari perilaku buruk (60\%) menjadi baik (90\%) karena penggunaan APD tanpa kebersihan 
tangan memungkinkan penyebaran untuk infeksi.

Beberapa hal yang dapat melatarbelakangi petugas dalam menerapkan prosedur yaitu menganggap tangan sudah cukup aman hanya dengan APD untuk mencegah infeksi nosokomial. Selain itu, kebersihan tangan sesuai prosedur dianggap terlalu rumit dan akan menambah beban kerja perawat dalam tindakan pada pasien. Di sisi lain, bahwa kebersihan tangan petugas dilakukan lebih tepat pada saat ada pengawasan langsung serta waktu yang terbatas.

Menurut Notoatmodjo (2010), faktor yang dapat dibangun dalam perilaku yaitu faktor predisposisi meliputi pengetahuan, sikap mendukung dan dorongan perawat menerapkan prosedur kerja. Perilaku yang didasarkan dengan pengetahuan dan sikap akan lebih baik dibandingkan dengan tidak didasarkan pengetahuan. Selain itu, motivasi petugas juga merupakan salah satu faktor penting dalam kepatuhan perawat melaksanakan prosedur kerja. Perawat yang memiliki motivasi bagus cenderung akan berperilaku lebih baik. Pengetahuan, sikap dan motivasi didukung beberapa faktor internal maupun eksternal yang diantaranya seperti karakteristik individu (umur, masa kerja/pengalaman, tingkat pendidikan, jenis kelamin), budaya, sumber informasi dan lainnya.

\section{METODE PENELITIAN}

Penelitian ini merupakan penelitian deskriptif kuantitatif dengan pendekatan cross sectional. Penelitian dilaksanakan di ruang rawat inap RSUD Kabupaten
Buleleng. Sampel dalam penelitian ini sebanyak 105 responden dengan menggunakan metode proportionated random sampling. Pengumpulan data menggunakan metode kuesioner dengan teknik analisis data menggunakan analisis deskriptif univariat.

\section{HASIL}

\section{Karakteristik Responden}

Sebagian besar responden perawat pada kelompok umur $\geq 30$, jenis kelamin perempuan, pada kelompok pendidikan Diploma, pada masa kerja $<5$ tahun dan sebagian besar responden perawat pada kelompok status kontrak.

\section{Tingkat Pengetahuan Responden}

Tabel 1 Gambaran Pengetahuan

\begin{tabular}{|c|c|c|}
\hline Pengetahuan & $\begin{array}{l}\text { Frekuensi } \\
\text { (orang) }\end{array}$ & $\begin{array}{l}\text { Proporsi } \\
(\%)\end{array}$ \\
\hline Baik & 60 & $57,1 \%$ \\
\hline Cukup & 30 & $28,6 \%$ \\
\hline Kurang & 15 & $14,3 \%$ \\
\hline Total & 105 & $100,0 \%$ \\
\hline $\begin{array}{l}\text { Responden } \\
\text { pengetahuan b } \\
\text { memiliki peng } \\
14,3 \% \text {. }\end{array}$ & $\begin{array}{r}\text { memili } \\
\text { \& yaitu sebe } \\
\text { tahuan ku }\end{array}$ & $\begin{array}{l}\text { ki tingkat } \\
\text { sar } 57,1 \% \text { dan } \\
\text { rang sebesar }\end{array}$ \\
\hline
\end{tabular}

Sikap Responden

Tabel 2 Gambaran Sikap

\begin{tabular}{lll}
\hline Sikap & $\begin{array}{l}\text { Frekuensi } \\
\text { (orang) }\end{array}$ & $\begin{array}{l}\text { Proporsi } \\
\text { (\%) }\end{array}$ \\
\hline Positif & 72 & $68,6 \%$ \\
\hline Negative & 33 & $31,4 \%$ \\
\hline Total & 105 & $100,0 \%$ \\
\hline
\end{tabular}

Sebagian besar responden perawat memiliki sikap positif yaitu sebesar $68,6 \%$ dan sebesar 31,4\% memiliki sikap negatif. 
Motivasi Responden

Tabel 3 Gambaran Motivasi

\begin{tabular}{lll}
\hline Motivasi & $\begin{array}{l}\text { Frekuensi } \\
\text { (orang) }\end{array}$ & $\begin{array}{l}\text { Proporsi } \\
\text { (\%) }\end{array}$ \\
\hline Tinggi & 63 & $60,0 \%$ \\
\hline Rendah & 42 & $40 \% \%$ \\
\hline Total & 105 & $100,0 \%$
\end{tabular}

Sebagian besar pada kategori motivasi tinggi yaitu sebesar $60,0 \%$ dan motivasi rendah sebanyak $40,0 \%$.

Pengetahuan Berdasarkan Karakteristik

\begin{tabular}{cccl}
\hline \multirow{2}{*}{ Variabel } & \multicolumn{3}{c}{ Pengatahuan } \\
\cline { 2 - 4 } & Baik & Cukup & Kurang \\
\hline Umur & & & \\
<30 Tahun & 14 & 23 & 15 \\
& $(26,9 \%)$ & $(44,2 \%)$ & $(28,9 \%)$ \\
230 Tahun & 46 & 7 & 0 \\
& $(86,8 \%)$ & $(13,2 \%)$ & $(0,0 \%)$
\end{tabular}

Jenis Kelamin

$\begin{array}{lccl}\text { Laki-laki } & 6 & 4 & 3 \\ & (46,2 \%) & (30,8 \%) & (23,0 \%) \\ \text { Perempuan } & 54 & 26 & 12 \\ & (58,7 \%) & (28,3 \%) & (13,0 \%)\end{array}$

Tingkat Pendidikan

$\begin{array}{cccl}\text { SPK } & 4 & 2 & 0 \\ & (66,7 \%) & (33,3 \%) & (0,0 \%) \\ \text { Diploma } & 20 & 23 & 15 \\ & (34,5 \%) & (39,7 \%) & (25,8 \%) \\ \text { S1/Ners } & 36 & 5 & 0 \\ & (87,8 \%) & (12,2 \%) & (0,0 \%) \\ \text { Masa Kerja } & & & \\ \text { <5 Tahun } & 10 & 22 & 14 \\ & (21,7 \%) & (47,8 \%) & (30,4 \%) \\ \text { 5-10 Tahun } & 22 & 6 & 1 \\ & (75,9 \%) & (20,7 \%) & (3,4 \%) \\ >10 \text { Tahun } & 28 & 2 & 0 \\ & (93,3 \%) & (2,67 \%) & (0,0 \%)\end{array}$

Status Kepegawaian

\begin{tabular}{lccc}
\hline Kontrak & 25 & 21 & $11(19,3 \%$ \\
& $(43,9 \%)$ & $(36,8 \%)$ & \\
Tetap & 35 & 9 & $4(8,3 \%$ \\
& $(72,9 \%)$ & $(18,8 \%)$ & \\
\hline
\end{tabular}

Sebagian besar responden perawat pada kelompok umur $\geq 30$ tahun memiliki tingkat pengetahuan baik yaitu sebesar $86,8 \%$. Responden jenis kelamin perempuan memiliki tingkat pengetahuan baik sebesar 58,7\% sedangkan laki-laki memiliki pengetahuan baik 46,2\%. Sebagian besar responden pendidikan S1/Ners memiliki pengetahuan baik sebesar87,8\%. Masa kerja $>10$ tahun cenderung memiliki pengetahuan besar sebesar 93,3\%, sedangkan $<5$ tahun memiliki pengetahuan cukup 47,8\%. Responden dengan status kepegawaian tetap memiliki pengetahuan baik $72,9 \%$, sedangkan status kontrak 43,9\%.

Sikap Berdasarkan Karakteristik

\begin{tabular}{|c|c|c|}
\hline \multirow{2}{*}{ Variabel } & \multicolumn{2}{|c|}{ Sikap } \\
\hline & Positif & Negatif \\
\hline \multicolumn{3}{|l|}{ Umur } \\
\hline$<30$ Tahun & $25(48,1 \%)$ & $27(51,9 \%)$ \\
\hline$\geq 30$ Tahun & $47(88,7 \%)$ & $6(11,3 \%)$ \\
\hline \multicolumn{3}{|c|}{ Jenis Kelamin } \\
\hline Laki-laki & $8(61,5 \%)$ & $5(38,5 \%)$ \\
\hline Perempuan & $64(69,6 \%)$ & $28(30,4 \%)$ \\
\hline \multicolumn{3}{|c|}{ Tingkat Pendidikan } \\
\hline SPK & $5(83,3 \%)$ & $1(16,7 \%)$ \\
\hline Diploma & $29(50,0 \%)$ & $29(50,0 \%)$ \\
\hline S1/Ners & $38(92,7 \%)$ & $3(7,3 \%)$ \\
\hline \multicolumn{3}{|l|}{ Masa Kerja } \\
\hline$<5$ Tahun & $21(45,7 \%)$ & $25(54,3 \%)$ \\
\hline 5-10 Tahun & $22(75,9 \%)$ & $7(24,1 \%)$ \\
\hline >10 Tahun & $29(96,7 \%)$ & $1(3,3 \%)$ \\
\hline
\end{tabular}

Status Kepegawaian 


\begin{tabular}{ccc}
\hline Tetap & $40(83,3 \%)$ & $8(16,7 \%)$ \\
\hline Berdasarkan & karakteristik umur,
\end{tabular}
bahwa sebagian besar responden perawat pada kelompok umur $\geq 30$ tahun memiliki sikap positif sebesar $88,7 \%$. Sedangkan perawat $<30$ tahun cenderung memiliki sikap negatif sebesar 51,9\%. Responden perawat dengan jenis kelamin perempuan memiliki sikap positif sebesar $69,6 \%$ dan laki-laki sebesar 61,5\%.Perawat dengan pendidikan S1/Ners memiliki sikap yang positif sebesar 92,7\%, Diploma 50,0\% dan SPK $83,3 \%$. masa kerja $>10$ tahun memiliki sikap positif yaitu sebanyak 96,7\%, sedangkan masa kerja $<5$ tahun cenderung memiliki sikap yang negatif sebesar $54,3 \%$. status kepegawaian tetap cenderung memiliki sikap yang positif yaitu sebesar 83,3\% dan status kerja kontrak memiliki sikap positif sebesar $56,1 \%$.

Motivasi Berdasarkan Karakteristik

\begin{tabular}{ccc}
\hline \multirow{2}{*}{ Variabel } & \multicolumn{2}{c}{ Sikap } \\
\cline { 2 - 3 } & Positif & Negatif \\
\hline Umur & & \\
$<30$ Tahun & $19(36,5 \%)$ & $33(63,5 \%)$ \\
$\geq 30$ Tahun & $44(83,0 \%)$ & $9(17,0 \%)$
\end{tabular}

Jenis Kelamin

$\begin{array}{lrr}\text { Laki-laki } & 9(69,2 \%) & 4(30,8 \%) \\ \text { Perempuan } & 54(58,7 \%) & 38(41,3 \%)\end{array}$

\section{Tingkat Pendidikan}

$\begin{array}{llr}\text { SPK } & 5(83,3 \%) & 1(16,7 \%) \\ \text { Diploma } & 23(39,7 \%) & 35(60,3 \%) \\ \text { S1/Ners } & 35(85,4 \%) & 6(14,6 \%)\end{array}$

\section{Masa Kerja}

$\begin{array}{llc}<5 \text { Tahun } & 18(39,1 \%) & 28(60,9 \%) \\ 5-10 \text { Tahun } & 18(62,1 \%) & 11(37,9 \%) \\ >10 \text { Tahun } & 27(90,0 \%) & 3(10,0 \%)\end{array}$

\section{Status Kepegawaian}

Kontrak $23(40,4 \%) \quad 34(59,6 \%)$

\begin{tabular}{ccc}
\hline Tetap & $40(83,3 \%)$ & $8(16,7 \%)$ \\
\hline Responden kelompok umur $\geq 30$ tahun
\end{tabular}
memiliki motivasi tinggi yaitu sebesar $83,0 \%$, sedangkan kelompok umur $<30$ tahun cenderung memiliki motivasi rendah yaitu sebesar $63,5 \%$. Jenis kelamin laki-laki memiliki motivasi tinggi yaitu sebesar 69,2\%, dan perempuan sebesar 58,7\%. Pendidikan S1/Ners memiliki motivasi tinggi yaitu $85,4 \%$, sedangkan, responden pendidikan Diploma cenderung memiliki motivasi rendah sebesar $60,3 \%$.

Masa kerja $>10$ tahun memiliki motivasi tinggi sebanyak 90,0\%, sedangkan responden dengan masa kerja $<5$ tahun cenderung memiliki motivasi rendah yaitu sebanyak 60,9\%. Status kepegawaian tetap sebagian besar memiliki motivasi tinggi sebesar 83,3\%, sedangkan status kepegawaian kontrak cenderung memiliki motivasi rendah yaitu sebesar $59,6 \%$.

\section{DISKUSI}

Hasil penelitian pengetahuan responden tentang keselamatan pasien terklait kebersihan tangan diperoleh data bahwa sebagian besar responden memiliki pengetahuan baik 57,1\%. Pengetahuan merupakan hasil tahu individu yang menjadi salah satu unsur penting dalam membentuk sikap individu dan akan membentuk perilaku, sehingga dapat dikatakan bahwa semakin pengetahuan baik dapat meningkatkan perilaku kerja seseorang (Notoatmodjo, 2010a).

Dilihat dari segi umur, sebagian besar responden umur $\geq 30$ tahun memiliki pengetahuan baik $86,8 \%$. Hal ini 
menunjukkan bahwa semakin matang umur seseorang cenderung memiliki pengetahuan baik. Penelitian oleh Kusumawati (2011), juga menyatakan bahwa perawat pada kelompok umur 4165 tahun cenderung memiliki pengetahuan baik dibandingkan dengan perawat kelompok umur 20-40 tahun. Sesuai dengan pendapat Wawan dan Dewi (2011), umur mempengaruhi daya tangkap dan cara berpikir seseorang sehingga semakin bertambah umur dan semakin cukup umur maka pengetahuan akan lebih baik karena lebih mudah untuk menerima informasi.

Responden S1/Ners cenderung memiliki pengetahuan baik sebanyak 87,8\%. Sesuai dengan penelitian Azis (2013) mengenai pemahaman perawat tentang pencegahan infeksi nosokomial, responden pendidikan tinggi sebagian besar memiliki pemahaman tinggi. Menurut Notoatmodjo (2010b), pendidikan sebuah proses mempelajari dan meningkatkan ilmu yang didapat individu. Semakin tinggi pendidikan seseorang maka banyak juga pengetahuan yang dimiliki.

Masa kerja $>10$ tahun memiliki pengetahuan baik dibandomngkan $<5$ tahun. Hal ini didukung oleh penelitian Rajcevic, dkk (2012), menyebutkan bahwa perawat yang bekerja $>20$ tahun cenderung lebih mengetahui prosedur kerja dibandingkan dengan masa kerja yang kurang dari $<20$ tahun. Menurut Notoatmodjo (2010a), seseorang akan mengingat dan belajar dari pengalaman yang didapatkan secara informal. Status kepegawaian tetap sebagian besar memiliki pengetahuan baik sebanyak $72,9 \%$. Hal tersebut dapat disebabkan karena dengan pekerjaan yang tetap individu memiliki kesempatan untuk mengikuti pelatihan berkala yang dilaksanakan oleh instansi sehingga dapat menambah pengetahuan yang dimiliki secara terus menerus. Penelitian oleh Sugeng, dkk (2014), menyebutkan bahwa responden sebagian besar memiliki pengetahuan baik dan sebagian besar merupakan responden status kepegawaian tetap.

Terkait sikap, sebagian besar responden memiliki sikap positif sebesar 68,6\%. Menurut Wawan dan Dewi (2011), sikap merupakan perasaan menerima atau menolak objek yang menimbulkan kecenderungan seseorang untuk bertindak dan berperilaku. Jika seseorang memiliki sikap positif, maka perilaku terhadap objek tersebut juga baik. Berdasarkan hasil penelitian, didapatkan bahwa pada kelompok umur $\geq 30$ tahun sebagian besar memliki sikap positif sebanyak 88,7\%. Hasil menunjukkan bahwa semakin bertambah umur maka semakin baik juga sikap individu. Menurut Wawan dan Dewi (2011) semakin cukup umur maka akan semakin matang seseorang dalam bekerja dan bersikap. Hal tersebut dikarenakan semakin bertambahnya usia, pengalaman dan pemahaman yang didapatkan seseorang semakin banyak sehingga menimbulkan respon ingin menerima atau menolak terhadap objek tertentu. 
Pendidikan S1/Ners memiliki sikap positif sebanyak $92,7 \%$. Pendidikan dapat memberikan serta menambah wawasan, pemahaman individu terhadap sesuatu. Hasil penelitian sejalan dengan Pasambo dan Rusmawati (2015), sebagian besar responden dengan pendidikan sarjana keperawatan yaitu 61,3\% dan hasil sikap positif. Menurut Azwar (2013) bahwa konsep, ilmu dan ajaran yang sudah diterima individu dalam memperoleh pengetahuan di lembaga pendidikan akan mempengaruhi sikap dan perilaku.

Pada masa kerja $>10$ tahun memiliki sikap positif sebanyak 96,7\%. Hal ini sesuai dengan penelitian Wulandari, dkk (2012) bahwa masa kerja memiliki keterkaitan dengan sikap perawat. Perawat dengan masa kerja $\geq 5$ tahun memiliki kecenderungan sikap mendukung yang baik dalam penerapan sasaran keselamatan pasien dibandingkan dengan masa kerja $<5$ tahun. Menurut Azwar (2013), pengalaman dapat menjadi dasar dalam pembentukan sikap. Sikap seseorang akan lebih mudah terbentuk malalui segala sesuatu yang telah dan pernah dialami. Status kepegawaian tetap memiliki sikap yang positif sebesar $83,3 \%$. Hal ini dapat disebabkan karena status pekerjaan tetap biasanya memiliki keterikatan dan tanggungjawab yang lebih besar terhadap instansi sehingga berusaha untuk mematuhi prosedur yang ada. Sesuai dengan Wawan dan Dewi (2011), pekerjaan merupakan kegiatan yang dilakukan secara berulang dan banyak tantangan. Pekerjaan dapat memberi kesempatan individu untuk berbagi pengalaman pribadi dan orang lain.

Terkait motivasi responden sudah memiliki motivasi tinggi sebesar 60,0\%. Soetrisno (2009) berpendapat, motivasi merupakan daya pendorong mengakibatkan seseorang untuk mengerahkan kemampuan dalam bentuk keahlian atau keterampilan untuk mencapai tujuan yang diinginkan. Responden dengan umur $\geq 30$ tahun memiliki motivasi tinggi sebanyak $83,0 \%$ dan responden dengan umur $<30$ tahun cenderung memiliki motivasi rendah sebesar 63,5\%. Hal ini dapat disebabkan seiring bertambahnya usia, seseorang ingin mempertahankan kualitas kerja untuk bertahan dalam pekerjaan. Robbins dan Judge (2008) menyatakan bahwa individu yang lebih tua memiliki komitmen lebih baik terhadap pekerjaan. Semakin tua maka kecil kemungkinan untuk berhenti serta mencari pekerjaan yang lain sehingga berusaha melaksanakan pekerjaan dengan baik dan mematuhi prosedur kerja yang tersedia.

Jenis kelamin laki-laki sebagian besar memiliki motivasi tinggi yaitu sebanyak $69,2 \%$. Hasil menunjukkan bahwa laki-laki memiliki motivasi tinggi dibandingkan perempuan. Sesuai dengan penelitian Ndama dan Aminuddin (2013) menyatakan bahwa meskipun perempuan dan laki-laki cenderung memiliki motivasi rendah, namun perawat laki-laki lebih banyak memiliki motivasi tinggi dibandingkan perempuan yaitu sebanyak $42,9 \%$. 
Pendidikan S1/Ners sebagian besar memiliki motivasi tinggi yaitu $85,4 \%$ dan pendidikan Diploma memiliki motivasi rendah sebanyak 60,3\%. Pengetahuan yang didapatkan seseorang dalam pendidikan merupakan unsur dapat mengembangkan kemampuan, sehingga semakin tinggi pendidikan maka semakin besar dorongan individu mengaplikasikan kemampuannya. Penelitain Susanti (2012) menyatakan bahwa perawat pendidikan diploma rata-rata memiliki motivasi rendah, sedangkan perawat sarjana ratarata memiliki motivasi tinggi lebih banyak.

Masa kerja $>10$ tahun cenderung memiliki motivasi tinggi sebanyak 90,0\% dan perawat dengan masa kerja $<5$ tahun cenderung memiliki motivasi rendah sebanyak 60,9\%. Hal ini sesuai dengan penelitian Pambudi, dkk (2018) menunjukkan bahwa perawat memiliki motivasi tinggi dan sebagian besar responden berada pada kelompok masa kerja $\geq 5$ tahun dibandingkan dengan masa kerja $<5$ tahun. Menurut Soetrisno (2009), terdapat kebijakan terhadap jaminan hidup di hari tua dan dengan masa kerja yang panjang sehingga individu akan lebih termotivasi untuk bertahan dalam pekerjaan.

\section{KESIMPULAN DAN SARAN}

Responden memiliki pengetahuan baik, sikap positif dan motivasi tinggi. Saran yang dapat diberikan, meskipun sebagian besar variabel sudah baik namun masih terdapat beberapa responden termasuk kategori kurang baik. Hal yang dapat dilakukan yaitu penyebaran informasi secara mendalam lagi sehingga responden dapat meningkatkan pengetahuan dan sikap secara terus menerus. Selain itu, pemberian motivasi oleh instansi khususnya oleh Tim kerja dapat memberikan dorongan petugas untuk meningkatkan kinerja.

\section{DAFTAR PUSTAKA}

Ariyanti, R. (2015). Hubungan Antara Motivasi Kerja Perawat Dengan Pelaksanaan Discharge Planning Di Ruang Rawat Inap RSU PKU MUHAMMADIYAH BANTUL.'

Azis, N. (2013). Faktor-Faktor yang Berhubungan dengan Pemahaman Perawat Dalam Upaya Pencegahan Infeksi Nosokomial Luka Pasca Bedah Di Ruang Perawatan II dan III RSUD H.Andi Sulthan Daeng Rdja Kab.Bulukumba Tahun 2013.

CDC. (2014). New CDC Guideline for Hand Hygiene In Health Care Settings.59-62.

Kemenkes RI. (2008). Panduan Nasional Keselamatan Pasien Rumah Sakit. Jakarta. 1-84.

Kemenkes RI. (2011). Program Pencegahan Dan Pengendalian Infeksi Nosokomial Merupakan Unsur Patient Safety. Jakarta

Kemenkes RI. (2017). Peraturan Menteri Kesehatan Republik Indonesia Nomor 11 Tahun 2017 Tentang Keselamatan Pasien. Jakarta.

Malliarou, M. (2017). Hand Hygiene of Nurses and Patient Safety. International Journal of Nurses and Patient Safety, 4, 217. 
Manorek, H., Rattu, A. J. M. dan Abeng, T. D. E. (2017). Faktor Yang Berhubungan Dengan Penerapan Sasaran Keselamatan Pasien Pada Perawat Di Ruang Rawat Inap Rumah Sakit Umum Daerah DR Sam Ratulangi Tondano. Naskah Publikasi, 65-76.

Meikawati, W. dan Susilawati (2010). Hubungan Pengetahuan Dan Sikap Petugas Penjamah Makanan Dengan Praktik Hiegiene Dan Sanitasi Makanan Di Unit Gizi RSJD Dr.Amino Gondohutomo Semarang. Jurnal Kesehatan Masyarakat, 6(1), 5064.

Ndama, M. dan Aminuddin (2013). Analisis Faktor-Faktor yang Berhubungan dengan Motivasi Perawat Dalam Pendokumentasian Asuhan Keperawatan Di Ruang Perawatan Umum Rumah Sakit Daerah Madani Palu. 57-65.

Ningsih, R., Noprianty, R. dan Somantri, I. (2017). Gambaran pelaksanaan kegiatan kebersihan tangan oleh petugas kesehatan di rumah sakit dustira cimahi.e-journal UPI, 57-68.

Notoatmodjo, S. (2010a) Ilmu Perilaku Kesehatan. Jakarta: Rineka Cipta.

Notoatmodjo, S. (2010b) Promosi Kesehatan Teori Dan Aplikasinya: Edisi Revisi. Jakarta: Rhineka Cipta.

Nugraheni, R., Suhartono dan Winarni, S. (2012). Infeksi Nosokomial di RSUD Setjonegoro Kabupaten Wonosobo. Media Kesehatan Masyarakat Indonesia, 11(1),94-100.
Robbins, S. P. dan Judge, T. (2008). Perilaku Organisasi Edisi 12. Jakarta: Selemba

Shinta, T., Setyarini, E. and Prtahama, M. (2008). Hubungan Pengetahuan dengan Sikap Perawat Dalam Pelaksanaan Family Centered Care Di Ruang Rawat Inap. 44-55.

Soetrisno, Edy. (2009). Manajemen Sumnber Daya Manusia. Kencana. Pernada Media Group

Sugeng, Ghofur, A. dan Kurniawati, L. (2014). Hubungan Pengetahuan dan Sikap Perawat Dengan Pencegahan Infeksi Nosokomial Di Ruang Rawat Inap Rumah Sakit Paru dr.Ario Wirawan Salatiga Jawatengah.

Susanti, E. (2013). Hubungan Karakteristik Perawat Dengan Motivasi Perawat Dalam Pemenuhan Kebutuhan Kebersihan Diri Pasien Di Ruang Rawat Inap RSU dr. H. Koesnadi Bondowoso.

WHO (2017). Patient safety: making health care safer. Ganeva. Available at: http://www.who.int/topics/patient_saf ety/en/.

Wulandari, N., Setyaningrum, R. dan Musafaah (2012). Hubungan Karakteristik Dan Pengetahuan Perawat Dengan Sikap Mendukung Penerapan Program Keselamatan Pasien Di RSUD Banjarbaru. Naskah Publikasi, p. 12.

Wulandari, R. dan Sholikah (2017). Pengetahuan Dan Penerapan Five Moments Cuci Tangan Perawat Di RSUD Sukoharjo. GASTER, XV(1). 